УДК 658.8.011.1:691

DOI: https://doi.org/10.37320/2415-3583/11.26

Фісун Ю.В.

старший викладач кафедри маркетингу,

Національний авіаційний університет

Арбора I.B.

студентка кафедри маркетингу,

Наиіональний авіаційний університет

\title{
ВИКОРИСТАННЯ МАРКЕТИНГОВИХ ІНСТРУМЕНТІВ У РОЗДРІБНІЙ ТОРГІВЛІ БУДІВЕЛЬНИМИ ТОВАРАМИ
}

У статті розглянуто основні маркетингові інструменти, застосування яких доцільне в роздрібній торгівлі будівельними матеріалами. Сучасні тендениії розвитку ринку продукиї будівельної галузі характеризуються за допомогою низки показників: обсягу і якості проектів; рівня орендних ставок, показника прибутковості, присутності великих іноземних компаній, роботи інвестиційних фондів. Із загостренням конкуренції за ринки збуmу, а також за дисбалансу попиту та пропозииї все більшої уваги до себе вимагає показник, який неможливо виразити математично, але він є індикатором якісних змін ринку, - важливість застосування маркетингових інструментів, ще використовуються в процесі збуту продукиії будівельної галузі. Однак необхідне використання всієї сукупності маркетингового інструментарію з просування та збуту продукиії будівництва.

Ключові слова: маркетинг, маркетингові дослідження, просування, маркетингові комунікації, канали збуту, будівельні матеріали, ритейл.

Постановка проблеми. Аналізуючи маркетингову діяльність будівельних фірм України, можна стверджувати, що сьогодні вони переважно вживають тільки окремі елементи маркетингу для просування і збуту своєї продукції. Тому необхідно мобілізувати всі можливі заходи будівельного маркетингу, і провідну роль у цьому відіграє маркетинговий інструментарій.

Аналіз останніх досліджень і публікацій. Важливість застосування та формування вдалого маркетингового інструментарію $\epsilon$ важливим фактором збільшення обсягів продажу. Це об'єднана діяльність усіх підсистем маркетингу, яка через певний проміжок часу приносить значний результат, що підвищує ефективність роботи підприємства загалом. Саме тому необхідність застосування маркетингових інструментів та визначення їхньої специфіки на ринку будівельної продукції розглядається в наукових працях як вітчизняних науковців, так і зарубіжних: В.В. Войтенко, С.С. Гаркавенко [2], В.Г. Герасимчука, Дж.М. Еванса, Є.В. Крикавського, Н.В. Куденко, В.А. Полторак [7], І.Л. Решетнікової, Є.В. Ромата, С.В. Скибінського, А.О. Старостіної, Х. Хершгена та багатьох інших. Однак, незважаючи на значну кількість наукових публікацій, присвячених дослідженню проблеми специфіки застосування маркетингу продукції будівельної промисловості, це питання залишається вивченим не досить.

Метою написання статті $€$ визначення необхідності та особливості застосування маркетингового інструментарію торговими підприємствами для покращення продажу будівельних матеріалів.
У процесі досліджень були використані такі методи: метод економічного аналізу, статистичний метод для узагальнення даних і виявлення закономірностей та явищ у конкретних умовах місця та часу, метод синтезу як метод вивчення об'єкта у його цілісності, у єдиному і взаємному зв'язку, метод аналізу стану ринку та інші.

Виклад основного матеріалу дослідження. На багатьох будівельних підприємствах України маркетингова діяльність проводиться не у повному обсязі. Це випливає з результатів опитування спеціалістів будівельних організацій різних форм власності, 3 яких 20\% маркетингову діяльність не проводять узагалі, на 56\% маркетингова діяльність зводиться до рекламної, збутової та виставкової діяльності, лише $24 \%$ підприємств виконують маркетингові функції - аналітичну, виробничу, збутову та функцію управління та контролю. Необхідність застосування маркетингового інструментарію для просування продукції будівельної галузі випливає 3 таких причин, як посилення конкуренції на ринку підрядних робіт. Безальтернативність цього ринку в недалекому минулому змінилася сьогодні досить жорсткою боротьбою за замовлення, причому конкуренція зростає в міру універсалізації більшості будівельних організацій; йде боротьба за замовників. Замовника вже не влаштовує виконання вузькоспеціалізованих робіт. Він віддає перевагу будівельній організації, яка здає об’єкти «під ключ», а також із комплексом послуг, що сприяють підвищенню споживчих якостей будівельної продукції, раціоналізації виробничих процесів. Для ефективного споживання будівельної продукції 
найчастіше необхідне сполучення технологій виробництва та споживання, що веде до зрощення фінішних операцій у будівництві зі стартовими операціями у споживачів і нерідко вимагає створення спеціальних збутових підрозділів, вирішення проблеми ефективності ринкової поведінки і розвитку будівельної організації. Ефективний збут не може бути заснований тільки на просуванні готової продукції на ринок, а обов'язково передбачає глибоке вивчення реального платоспроможного попиту споживачів і подальшу орієнтацію виробництва на його задоволення.

Правильно проведене маркетингове дослідження дає змогу суб' єкту господарювання ефективніше виконувати свої бізнес-завдання. Методи маркетингових досліджень значно залежать від конкретних цілей та завдань маркетингу, що визначається загальною маркетинговою стратегією компанії, маркетинговою ситуацією, тиском конкурентів тощо. Водночас існують сталі підходи до проведення маркетингових досліджень, які виражаються у певній послідовності етапів, які разом забезпечують їхню належну ефективність. До специфічних методів дослідження роздрібної торгівлі належать:

Retail Audit - це моніторинг, перевірка і контроль рівня представленої продукції в торгових точках, що дає можливість оцінити товар на ринку. Цей вид маркетингових досліджень успішно використовується компаніями, і його застосування дає якісний результат у проведенні потрібної кампанії.

Retail Monitoring - це періодичне вивчення цінової ситуації на ринку, завданням якого $\epsilon$ оцінка асортименту і цінової політики торгової компанії, пошук шляхів коригування цінової політики компанії.

Торгова панель - це техніка, спрямована насамперед на збір інформації про продажі. За допомогою такого дослідження фіксуються такі показники, необхідні для ефективного маркетингу, як: ємність і тенденції ринку для кожного різновиду і бренду в обсягах продажів цього товару, його розподіл за типами магазинів і регіонами; використання різних способів залучення покупців (знижки, купони, бонуси); специфіка і розміри упаковки товарів, що продаються; специфіка ціноутворення і ділової політики; наявність (відсутність) певних товарів у відповідний період готовності їх придбати.

Store checking - метод дослідження, спрямований на вивчення асортименту товарів і цінових діапазонів товарів різних товарних груп, найменувань, брендів. Ви можете отримати інформацію 3 широкого кола питань, таких як: асортимент i структура торгової пропозиції (за найменуваннями, товарними групами, брендами, виробниками, типами торгових точок); відмінності між оптовими і роздрібними цінами; торгові стратегії конкурентів; непрямі оцінки частки ринку і продажів товарів різних найменувань, виробників, брендів і так далі.

Mystery shopping - це метод анонімної оцінки якості обслуговування клієнтів, роботи обслуговуючого персоналу, дотримання стандартів персоналу і мерчандайзингу, а також оцінки якості продукціїіпослугзадопомогоюспеціальнихаудиторів, які виступають у ролі покупців чи споживачів.

ABC-аналіз, XYZ-аналіз - методи, засновані на використанні математичних розрахунків і засновані на принципі Парето (20\% продукту генерує $80 \%$ доходу). Використання цих методів дає змогу оцінити цінність товарних груп, підгруп, брендів для магазину, вибір методів роботи 3 ними; оцінити стабільність продажів товарів різних типів попиту, різних цінових категорій, різного обороту; знайти шляхи оптимізації асортименту; проаналізувати розподіл торгових площ і поличних площ, ефективність їх використання. У процесі дослідження була отримана інформація про товарні групи, стабільність їх продажів; рентабельність товарних груп; швидкість реалізації.

Без проведення маркетингових досліджень жодна компанія не зможе правильно орієнтуватися у складній ринковій ситуації, достовірно оцінювати своє становище на ринку, а також прогнозувати свій подальший розвиток. Маркетингові дослідження - це, мабуть, єдиний спосіб отримати унікальну інформацію про ринок, без якої маркетинг - всього лише марна теорія [5].

В умовах жорсткої конкуренції ключовим пріоритетом маркетингової діяльності ритейлерів $\epsilon$ формування стійких відносин із покупцями. Конкурентну перевагу отримують ті компанії, які здатні забезпечити задоволеність і лояльність клієнтів. Надзвичайно важливу роль у формуванні цієї задоволеності відіграють не тільки асортимент і якість пропонованих товарів, приваблива цінова політика, організація продажів, але і маркетингові комунікації. Сьогодні комерційні комунікації роздрібних торговців повинні перетворитися 3 агресивного, переконливого інструменту просування послуг, який часто дратує потенційних споживачів, на ефективний інструмент передачі споживачеві потрібної інформації найбільш зручним і доступним способом.

Управління маркетинговими комунікаціями підприємств роздрібної торгівлі слід побудувати на таких принципах, як: цілеспрямованість; клієнтоорієнтованість; специфічність; інтегрованість; інтерактивність; індивідуалізація; оптимальність; соціальна етичність.

Основними цілями маркетингових комунікацій для ритейлерів $\epsilon$ формування іміджу бренду; залучення споживачів до відвідування торгових точок; стимулювання здійснення покупки; сприяння задоволенню споживачів; забезпечення спо- 
живчої лояльності. Для досягнення цих цілей підприємства використовують цілу низку видів маркетингових комунікацій (реклама, стимулювання збуту, «зв’язки 3 громадськістю», директмаркетинг, інтегровані маркетингові комунікації у сфері продажів, особисті продажі). У межах кожного виду доцільно розрізняти підтипи традиційних і електронних комунікацій.

Впровадження сучасних інформаційно-комунікаційних технологій у роздрібній торгівлі потребує перегляду маркетингових та функціональних стратегій, зокрема комунікативних та маркетингових. Залежно від інструментів Інтернет-маркетингу, цифрових інструментів та їхнього взаємозв'язку можуть використовуватися різні маркетингові стратегії [4].

Для того щоб більш ефективно взаємодіяти та надавати покупцям нескінченні можливості здійснювати покупки в будь-який час, у будь-якому місці, будь-якими найбільш зручними для них способами, необхідно використовувати всі можливі канали продажів, які до того ж повинні бути взаємно узгоджені. Такий підхід створює універсальну стратегію продажу, відповідно до якої використовується безліч різних каналів, і кожен iз них максимально узгоджений 3 іншими каналами і надає необмежені можливості для пошуку товару, ознайомлення з пропозиціями продавця, здійснення вибору, замовлення, оплати.

Для реалізації комплексного підходу до організації роздрібних продажів підприємствам необхідно: розробити маркетингову стратегію на основі використання традиційних і цифрових маркетингових інструментів; максимально використовувати цифрові канали та засоби зв'язку i взаємодії 3 потенційними покупцями; прямі зусилля по всіх каналах для зміцнення цінності бренду; вивчення не тільки купівельної, але і «цифрової» поведінки покупців, визначення наявності цифрових пристроїв, способів їх використання, мобільних додатків і готовності до їх використання під час покупки; забезпечити високий рівень обслуговування клієнтів і безперервну оптимізацію процесів взаємодії 3 клієнтами; моніторинг як офлайн-, так і онлайн-конкурентів; розроблення та реалізація креативних ідей під час розроблення дизайну та контенту цифрових медіа, проведення маркетингових заходів; залучення фахівців із цифрового маркетингу, створити відповідні організаційні структури на підприємстві - відділи та служби; забезпечення високого рівня інтеграції та взаємозв'язку між застосовуваними каналами продажів [1].

Оскільки навіть найкращий товар не може продати себе сам, ритейлер повинен забезпечити, щоб продукти були ефективно представлені в магазині, переконати покупців придбати товар і запропонувати послуги, які будуть стимулювати і підтриму- вати рішення споживача про покупку. Комплекс заходів, спрямованих на просування і продаж товарів у магазині, називається мерчандайзингом. Ці заходи дають змогу створити позитивний імпульс для споживачів не тільки до покупки, але i до створення іміджу бренду у свідомості покупця. Тому мерчандайзер робить товарну пропозицію рельєфною, тобто кожен товар повинен чимось виділятися, а загальний макет не повинен бути однорідним сірим фоном. Світовий досвід показує, що продажі можна збільшити майже на 400-600\%, якщо просто правильно поставити продукт.

Фахівці у сфері мерчандайзингу схиляються до того, що стандартним комплексом маркетингу, що складається 3 4Р, покупця не здивуєш. На цьому етапі розвитку роздрібної торгівлі та маркетингу створюється додатковий елемент - послуга 3 мерчандайзингу, яка, об'єднавшись із товаром у місці продажів, утворює єдиний товарний комплекс (товар + послуга). Це остаточний продукт, цінність якого підвищується за рахунок послуги, створеної в місцях продажів самим торговцем, виробником або агентством, що спеціалізується в цій сфері. Її і купує споживач разом із товаром [3].

В умовах реалізації сучасної концепції маркетингу відносин для підприємств роздрібної торгівлі актуальним $є$ перехід від стимулювання до мотивування. Відсутність єдиного підходу до визначення теоретичних аспектів мотивування учасників відносин зумовила необхідність уточнення поняття «мотивування», його місця у межах сучасної концепції. Відзначено, що мотивування учасників відносин підприємства роздрібної торгівлі, таких як споживачі, постачальники, посередники, конкуренти та контактні аудиторії, відбувається у межах мотиваційного поля, в якому запропоновано виділяти неконтрольовану та контрольовану частини. Неконтрольована частина мотиваційного поля сформована із мотивів та інтересів учасників відносин із підприємством, на які воно впливати не може, тоді як до контрольованої частини віднесено комплекс маркетингу підприємства роздрібної торгівлі, а кінцевим результатом його впливу на споживачів є забезпечення їхньої лояльності.

Саме ефективне мотивування покупців підприємствами роздрібної торгівлі забезпечується знаннями про особливості купівельної поведінки споживачів та фактори, що їі визначають. Модель купівельної поведінки споживача та вибору торговельного об'єкта зокрема може бути представлена трьома типами прийняття рішень, що визначається сукупністю зовнішніх та внутрішніх чинників. До факторів впливу на купівельну поведінку споживача віднесемо: фізичне оточення та матеріальні складники, соціальне оточення, час, мету споживача, його попередній досвід. Підприємства роздрібної торгівлі розробляють відповідні про- 
грами впливу, забезпечують задоволення потреб, підвищують якість торговельного обслуговування та збільшують обсяги реалізації товарів.

Такий підхід дасть змогу сформулювати завдання та обгрунтувати інструменти мотивування окремих сегментів споживачів.

Забезпечення лояльності споживача можливе за рахунок створення умов, за яких він може бути мотивований до повернення та збільшення обсягів покупок. Такі умови забезпечуються дією маркетингових інструментів мотивування покупців елементами комплексу маркетингу підприємства роздрібної торгівлі.

Під час формування набору маркетингових заходів потрібно чітко розуміти, що маркетингові інструменти не використовуються незалежно один від одного. Вони мають доповнювати один одного. Недостатня координація може привести до тимчасової нейтралізації впливу різноманітних інструментів. У результаті має бути отримана інформація про попит; про пропозицію; про можливість використання інструментів маркетингу і їхню ефективність.

Закони маркетингу однакові для всіх продуктів, проте маркетинговий інструментарій для кожного окремого виду продукції має низку особливостей. Сукупність маркетингових інструментів, що застосовуються у процесі створення та просування будьякого продукту, визначається, виходячи 3 поставлених цілей, і коригується залежно від специфіки останнього. Так, зокрема, під час організації маркетингової діяльності будівельного підприємства необхідно враховувати низку особливостей, основними 3 них $є$ : недосконалість і нестабільність нормативно-правової бази, яка регулює діяльність підприємств будівельного сектору економіки, у результаті чого досить вільно трактуються й постійно змінюються державні та регіональні «правила гри»; відсутність достовірної і правильної інформаціїпро стан будівельного ринку; вирішальна роль суб'єктивного фактора у виборі замовником підрядної будівельної організації, коли визначальним $є$ рівень особистих відносин керівників підприємств; висока можливість фінансових і іміджевих ризиків у найближчому майбутньому компанії; низька мобільність будівельної організації та інші.

У ринкових умовах господарювання дедалі більшого значення набуває використання посе- редників для просування продукції. Незважаючи на те, що збут через посередників має як позитивні, так і негативні сторони, на ринку будівельних матеріалів вони мають особливе значення. Це пояснюється тим, що для ринку будівельної продукції характерна велика різноплановість споживачів, що відрізняє його від інших ринків.

Поняття «посередницькі компанії» ще не набуло поширення в українській економіці, хоча їхня роль зростає завдяки тим вигодам, які вони надають як виробникам, так і споживачам. Використання посередницької мережі для продажу продукції дає змогу охопити більшу кількість покупців і врахувати інтереси всіх сторін договору [2].

Висновки. Беручи до уваги всі ці особливості будівельного ринку, а також специфіку застосування маркетингових заходів для просування товарів на ньому, підприємствам будівельної галузі можна запропонувати комплекс заходів для удосконалення збуту будівельної продукції, який включає такі підходи, як: комплексна збутова політика; застосування соціально-етичного підходу; активна асортиментна політика; застосування нових форм організацій продажу будівельних матеріалів, що грунтуються на використанні сучасних досягнень; посилення ролі маркетингових досліджень під час прийняття управлінських рішень збутового характеру. Такий напрям удосконалення збутової діяльності насамперед пояснюється головним завданням маркетингових досліджень - моніторингом ринків із метою виявлення обсягу попиту на продукцію підприємства на них, а також визначенням тих ринків, де продажі обіцяють бути більш успішними; підвищенням кваліфікації торгового персоналу. Для того, щоб повною мірою задовольнити інформаційні запити потенційних покупців, торговельний персонал підприємства має володіти всією необхідною інформацією стосовно пропонованого ним товару. Особливо це стосується технологічно та технічно складних товарів; розширення роздрібної торгової мережі.

Підводячи підсумок, можна стверджувати, що маркетинг будівельної продукції - це діяльність спеціалізованих будівельних організацій із дослідження ринку будівельної продукції, оцінки, прогнозування та створення попиту на неї, яка орієнтована на максимізацію прибутку.

\section{Список використаних джерел:}

1. Галайдіда О. Специфіка маркетингового інструментарію на ринку будівельних матеріалів : матеріали Всеукраїнської студентської інтернет-конференції м. Чернівці, 4 травня $2011 \mathrm{p}$ : Чернівецький національний університет імені Юрія Федьковича, 2011. URL: http://conf-cv.at.ua/forum/52-450-1 (дата звернення: 13.04.2020).

2. Гаркавенко С.С. Маркетинг. Київ : Лібра, 2010. 720c.

3. Мица В.В., Кривончак В.М., Серветник В.М. Шляхи вдосконалення виробництва і збуту продукції будівельної галузі для підвищення конкурентоспроможності в умовах ринку. Вісник Хмельнищького нащчіонального університету. 2010. № 6, Т. 3. С. 83-89.

4. Снегирева В.В. Книга мерчандайзера : СПб. Питер, 2007. 384 с. 
5. Григорчук Т.В. Маркетинг. Частина друга. URL: www.sites.google.com/site/marketingdistance (дата звернення: 14.04.2020).

6. Озмитель М. Маркетинговые исследования в розничной торговле. URL: www.retailkyrgyzstan.com/opening.astore/ marketing.surveys.htm (дата звернення: 10.04.2020).

7. Полторак В.А. Маркетингові дослідження : навчальний посібник. Київ : Центр навчальної літератури, 2003. 387 с.

\section{References:}

1. Halaida O. (2011) Spetsyfika marketyngovogo instrumentariu na rynku budivelnykh materialiv [Specifics of the construction goods' marketing toolkit]. Proceedings of the National Ukrainian Student Online-Conference (Ukraine, Chernivtsi, May 4, 2011) Available at: http://conf-cv.at.ua/forum/52-450-1 (accessed 13 April 2020).

2. Harkavenko S. S. (2010) Marketynh [Marketing]. Kyiv: Libra. (in Ukrainian)

3. Mytsa V.V. (2010) Shlyakhy vdoskonalenya vyrobnytstva i zbutu produksii budivelnoyi galuzi dlya pidvushchenya konkurentospromozhnosti $\mathrm{v}$ umovakh rynku [The measures of production and distribution development of construction goods in order to increase the competitive presence at the market]. The Bulletin of Khmelnytskyi National University, vol. 3, no 6, pp. 83-89.

4. Snegyreva V.V (2007) Knyha Merchendaizera [A book of a merchandiser]. Saint Petersburg. (in Russian)

5. Hryhorchuk T.V. (2015) Marketynh [Marketing]. Available at: www.sites.google.com/site/marketingdistance (accessed 13 April 2020).

6. Ozmytel' M. (2015) Marketynhovi doslidzhennya v rozdribniy torhivli [Marketing research in retail trade]. Available at: www.retailkyrgyzstan.com/opening.astore/marketing.surveys.htm (accessed 10 April 2020).

7. Poltorak V.A. (2003) Marketynhovi doslidzhennia [Marketing researches]. Kyiv: Center for educational literature. (in Ukrainian)

Fisun Iuliia, Arbora Iryna

National Aviation University of Kyiv

\section{THE USE OF MARKETING TOOLS IN CONSTRUCTION GOODS'RETAIL TRADE}

The main purpose of the article is to take a closer look at the fundamental marketing tools that can be perceived as extremely profitable and efficient in the retail trade of construction materials. According to the analysis of the marketing activities of companies in the construction industry, we can say that they mainly use certain elements of marketing. Therefore, there is a problem to mobilize all possible measures of construction marketing, namely the use of marketing tools. Today, trade enterprises operate in a highly competitive environment, so they have to analyze the impact of market relations and take the necessary measures to adapt.

As a matter of fact, it is something undeniable in terms of the how market economy works, where the buyer of goods or services should be considered as the master of a situation. That is why companies that are engaged in retail trade are forced to study the market and also work on the principles of marketing.

Modern trends in the development of the market for construction products are characterized by a number of indicators: volume and quality, the level of rental rates, profitability, the presence of large foreign companies, and so on. However, with increasing competition for sales markets, as well as with an imbalance of supply and demand, an indicator that cannot be expressed mathematically requires more attention, but it is an indicator of qualitative changes in the market - the importance of using marketing tools used in the process of selling goods in the construction industry. However, to balance market processes, it is not enough to implement a structural transformation of the industry with a focus on meeting the needs of consumers, and it is also necessary to use the entire set of marketing tools.

All this leads to an awareness of the need to conduct marketing researches, the need to apply and develop successful marketing tools, this is a reliable means of increasing sales of products, and it is this combined activity of all marketing subsystems, which after a certain period of time will bring a significant result and increase the efficiency of the enterprise as a whole.

Key words: marketing, marketing research, promotion, marketing communications, distribution channels, construction/building goods, retail.

JEL classification: M11, M31, M39. 